www.jmscr.igmpublication.org

Index Copernicus Value: 79.54

ISSN (e)-2347-176x ISSN (p) 2455-0450

crossrefDOI: https://dx.doi.org/10.18535/jmscr/v7i2.196

\title{
Morphological Spectrum of Pediatric Central Nervous System Tumors- A seven year study from Central India
}

\author{
Authors \\ Avinash Gupta $^{1}$, Sukhpreet Kaur ${ }^{2}$, Hanni G Vasudev ${ }^{3}$ \\ *Corresponding Author \\ Avinash Gupta \\ Formerly Senior Resident BMHRC Bhopal, India
}

\begin{abstract}
Introduction: Tumors of the nervous system are important cause of cancer-related deaths in children. There are several reports regarding the epidemiology of CNS tumors in children in the Western literature but too few reports from India.

Material and Methods: A retrospective study was done on all the pediatric CNS tumors (less than 18 years) that were received in Pathology department over duration of seven years at Bhopal Memorial Hospital and Research Centre, Bhopal, India. All the adult CNS cancers were excluded in the study. All the selected cases were analyzed for age, sex, location of tumour and histomorphological findings, special stain and Immunohistochemical markers.

Results: Pediatric CNS tumor constitutes $10.25 \%$ (48/468) of total CNS tumors. Age range from 3 to 18 years with mean age of 11.2 years, Male: female ratio is 1.1:1. Children (0-14years) accounted for 34 cases with 16 males (47\%) and 18 (53\%) females. Adolescents (>14-18years) accounted for 14 cases with 9 males (64\%) and 5 females (36\%). 66.6\% tumors are infratentorial or spinal while $33 \%$ are supratentorial. Frequency of infratentorial/spinal tumor is high in both children as well as pediatric group. Histopathologically astrocytic tumors were most common (33.6\%) and pilocytic astrocytoma (15\%) is most frequent astocytic tumor. Embryonal tumours constitute $25.3 \%$ cases.

Conclusion: Due to limited resources, in this context, the adequate epidemiologic data is lacking from India. The present study was done to profile the prevalence of pediatric CNS tumors (according to the WHO classification 2016) in a tertiary care setup in Central India having good neurosurgical and neuropathology facilities, and the data was compared with international studies.

Keywords: CNS tumors, Pediatric tumors.
\end{abstract}

\section{Introduction}

Tumors of the nervous system are the second most common childhood tumor after leukemia, constituting approximately $35 \%$ of all childhood malignancies and remain the leading cause of cancer-related deaths in children. ${ }^{(1)}$

Childhood central nervous system (CNS) tumors differ significantly from adult brain tumors in reference to their sites of origin, clinical presentation, tendency to disseminate early, histological features and their biological behavior. ${ }^{(2)}$ Whereas in adults the predominant CNS tumor types are metastases, glial neoplasms and meningiomas, in children, besides gliomas, other major tumor types including primitive embryonal neoplasms are also common. ${ }^{(3)}$ 
In recent times, distinct molecular and genetic pathways and therapeutic approaches for each tumor type lead to an enhanced understanding of these biological differences between adult and childhood CNS neoplasms. There are several reports regarding the epidemiology of CNS tumors in children in the Western literature. Due to lack of resources, in this context, the adequate epidemiologic data lacks from India. Thus it is imperative to find out the prevalence and spectrum of different CNS tumors in pediatric age group and analyse the presenting signs and symptoms, location of tumour and histomorphological findings, special stain and Immunohistochemical markers.

\section{Material and Methods}

This is a retrospective study. We will include all the pediatric CNS tumors (less than 18 years) that were received in Pathology department between January 2010 to December 2016 at BMHRC, Bhopal, India. All the selected cases will be analyzed for age, sex, location of tumour and histomorphological findings, special stain and Immunohistochemical markers. Adult population suspected metastatic tumors, tumour-like cystic lesions and space occupying lesions of infectious etiology were excluded. Cases were diagnosed according to WHO (2016). ${ }^{(4)}$

\section{Note}

- Diagnosis of many tumors is based on the combined phenotypic and genotypic characteristics. At this point of time our institute lacks access to new IHC markers like IDH1, ATRX, TERT and molecular diagnostic testing of these tumors. As recommended in the new classification a diagnostic designation NOS (i.e., not otherwise specified) is permissible for some tumour types. "NOS" designation defines a group of lesions that cannot be classified into any of the more narrowly defined groups. The tumors were diagnosed according to 2016
World health organization (WHO) classification system $^{(4)}$.

- Astrocytoma - Astrocytoma, NOS

- Glioblastoma - Glioblastoma, NOS

- Embryonal tumors - Medulloblastoma, NOS + PNET+AT/RT.

Hemangiopericytoma (HPC) and solitary fibrous tumors (SFT) are combined in a single category of SFT/HPC and assigned three grades

Study Duration: Retrospective data of last of six years at Bhopal Memorial Hospital and Research Centre, Bhopal, India from January. 2010 to December 2016 was taken and entered in MS Excel.

\section{Results}

In the present study pediatric CNS tumor constitutes $10.25 \%(48 / 468)$ of total CNS tumors. Age range from 3 to 18 years with mean age of 11.2 years, Male: female ratio is 1.1:1. Cases are further grouped as Children (0-14years) and Adolescents (>14-18years) Children (0-14years) accounted for 34 cases with 16 males $(47 \%)$ and $18(53 \%)$ females. Adolescents (>14-18years) accounted for 14 cases with 9 males (64\%) and 5 females $(36 \%) .66 .6 \%$ tumors are infratentorial or spinal while $33 \%$ are supratentorial. Frequency of infratentorial/spinal tumor is high in both children as well as pediatric group. The histopathological spectrum and mean age these 48 cases of pediatric brain tumors are shown in table 1 . Histopathologically Astrocytic tumors were most common (33.6\%) and pilocytic astrocytoma $(15 \%)$ is most frequent astocytic tumor. Embryonal tumors are the second most common tumour found in this study, constituting $25.3 \%$ cases. Embryonal tumor includes medulloblastoma, Primitive neuroectodermal tumor (PNET) and Atypical teratoid/rhabdoid tumor (AT/RT). Other less frequent cases includes schwannoma $10.3 \%$, ependymoma $8-3 \%$, craniopharyngioma $6-3 \%$ hemangiopericytoma/ solitary fibrous tumor $4-2 \%$. 


\section{JMSCR Vol||07||Issue||02||Page 1121-1126||February}

Table 1 The histopathological spectrum and mean age of pediatric brain tumors

\begin{tabular}{|l|c|c|c|c|}
\hline Histologic type & No of cases & $\%$ & Mean age & M:F \\
\hline Pilocytic astrocytoma & 07 & 15.0 & 10.28 & $0.4: 1$ \\
\hline Diffuse astrocytoma, NOS & 04 & 8.3 & 12.75 & $1: 1$ \\
\hline Pilomyxoid astrocytoma & 01 & 2.0 & 13 & 1 \\
\hline Glioblastoma, NOS & 04 & 8.3 & 12.25 & $0.3: 1$ \\
\hline Total astrocytic tumors & 16 & 33.6 & 12.07 & $0.6: 1$ \\
\hline Ependymoma & 04 & 8.3 & 14.75 & $3: 1$ \\
\hline Schwannoma & 05 & 10.3 & 16.6 & $3: 2$ \\
\hline Medulloblastoma, NOS & 09 & 19.0 & 7.22 & $2: 1$ \\
\hline SFT/ Hemangiopericytoma & 02 & 4.2 & 15 & 1 \\
\hline CNS embryonal tumour ,NOS/PNET & 03 & 6.3 & 8.5 & $1: 2$ \\
\hline Craniopharyngioma & 03 & 6.3 & 11.33 & $2: 1$ \\
\hline Germinoma & 01 & 2.0 & 12 & M \\
\hline Pineoblastoma & 01 & 2.0 & 14 & F \\
\hline Meningioma & 01 & 2.0 & 15 & M \\
\hline Non Hodgkins Lymphoma -B cell type & 01 & 2.0 & 5 & M \\
\hline Chordoma & 01 & 2.0 & 6 & F \\
\hline Lipoma with tethered cord & 01 & 2.0 & 9 & F \\
\hline
\end{tabular}

\section{Discussion}

CNS tumors are the second most common childhood tumors after leukemia. (Approx. 35\% of all childhood malignancies) and Leading cause of cancer-related deaths in children. Mean age in present study is 11.2 and $\mathrm{M}$ : $\mathrm{F}$ ratio is $1.1: 1$ which is similar to previously published studies. Table 2 and 3 compares mean age and $\mathrm{M}$ : $\mathrm{F}$ ratio between our study and other Indian and international studies.

Table 2 Comparison of age and sex from Indian studies

\begin{tabular}{|c|c|c|c|c|c|}
\hline Study name & $\begin{array}{c}\text { Present } \\
\text { study }\end{array}$ & $\begin{array}{c}\text { Subhlaxmi et } \\
\text { al }^{(5)}\end{array}$ & $\underset{(6)}{\text { Harshil et al }}$ & $\begin{array}{l}\text { Ayushi jain } \\
\text { et }_{\text {al }}{ }^{(3)}\end{array}$ & $\begin{array}{c}\text { Sangeeta et } \\
\text { al }^{(7)}\end{array}$ \\
\hline Study period & $6 y r s$ & $2.5 \mathrm{yrs}$ & $2 \mathrm{yrs}$ & variable & 15 \\
\hline Total number of cases & 48 & 61 & 76 & 3936 & 239 \\
\hline Age group & $0-18 y r s$ & $0-15$ yrs & $0-19$ & $0-18$ & $0-18$ \\
\hline Mean age & $11.2 \mathrm{yrs}$ & $9.3 \mathrm{yrs}$ & 10.69 & - & - \\
\hline M:F & $1.1: 1$ & - & $1.2: 1$ & - & $1.2: 1$ \\
\hline
\end{tabular}

Table 3 Comparison of age and sex from international studies

\begin{tabular}{|c|c|c|c|c|c|}
\hline Study name & $\begin{array}{l}\text { Present } \\
\text { study }\end{array}$ & $\begin{array}{c}\text { Germany } \\
\left(\text { Kaatsch et al }^{(8)}\right)\end{array}$ & $\begin{array}{c}\text { Pakistan } \\
\text { (Ahmed et } \\
\left.\text { al }^{(9)}\right)\end{array}$ & $\begin{array}{c}\text { Nigeria } \\
\left(\text { Gabriel et }^{\text {al }}{ }^{(10)}\right)\end{array}$ & $\begin{array}{c}\text { Japan } \\
{\left.\text { (Makino et } \text { al }^{(11)}\right)} \text { ) }\end{array}$ \\
\hline Total number of cases & 48 & 3,268 & 81 & 77 & 210 \\
\hline Age group & $0-18$ yrs & $<15$ & $<15$ & $<15$ & $<15$ \\
\hline Mean age & $11.2 \mathrm{yrs}$ & 10.7 & 8.8 & 7.2 & NS \\
\hline $\mathrm{M}: \mathrm{F}$ & $1.1: 1$ & $1.2: 1$ & $2.5: 1$ & $1.3: 1$ & $1.3: 1$ \\
\hline
\end{tabular}

Comparison of location: Infratentorial and spinal tumors were more common than supratentorial tumor in present study. Similar findings were published by Ahmed et al ${ }^{(9)}$ (Pakistan). However Kaatsch et $\mathrm{al}^{(8)}$ (Germany) and Gabriel Olabiyi Ogun et al ${ }^{(10)}$ (Nigeria) found Equal ratio between supra- and infra-tentorial tumors. Other studies of Rosemberg et $\mathrm{al}^{(1)}$, Zhou et $\mathrm{al}^{(12)}$, Asirvatham et $\mathrm{al}^{(13)}$, Pinho et $\mathrm{al}^{(14)}$ respectively from China, South Korea, India and Brazil show a preponderance of supratentorial tumors. 
Morphologic spectrum: In our study, the two commonest pediatric tumors were pilocytic astrocytomas and medulloblastomas. Similar results were shown in the study published by Sengupta et $\mathrm{al}^{(6)}$. Astrocytic tumors are the most common Pediatric Brain tumors usually located in Cerebellum (posterior fossa). Pilocytic astrocytoma (grade-I) was the most common astrocytic tumor in our study. ( $17 \%$ of all CNS tumors in 0-14 year olds). Comparision of astrocytic tumors from other studies of India is shown in Table 4. Embryonal tumors were the second most common constituent of this study and most common non astrocytic tumour. Embryonal tumors - develops from embryonic cells remaining in the CNS after birth. Overall embryonal tumor incidence ranged from $0.28-0.80$ cases/1 lakh children (0-14 years). There are three major embryonal tumor types (1) Medulloblastoma (MB)- Avg. annual age-adjusted incidence rate 0.20-0.58 cases/1 lakh persons.(2) Primitive neuroectodermal tumor (PNET)- Average annual age-adjusted incidence rates from $0.08-0.21$ cases/100,000 children.(3) Atypical teratoid/ rhabdoid tumor (AT/RT)-0.07-0.14/100,000. Medulloblastoma (mb): Most common embryonal tumors(19\%) in the present study and all cases have posterior fossa involvement. Mostly occurs in $0-14$ yr age group.

Table 4 Comparison of astrocytic tumors with other studies from India

\begin{tabular}{|c|c|c|c|c|c|}
\hline Study name & $\begin{array}{l}\text { Present study } \\
\text { No / \% }\end{array}$ & $\begin{array}{c}\text { Subhlaxmi et } \\
\text { al }^{(5)} \%\end{array}$ & $\begin{array}{c}\text { Harshil et al }^{(6)} \\
\%\end{array}$ & $\underset{\text { (3) }}{\operatorname{Ay} \%}$ & $\begin{array}{c}\text { Sangita et } \mathbf{a l}^{(7)} \\
\%\end{array}$ \\
\hline $\begin{array}{l}\text { Pilocytic } \\
\text { astrocytoma }\end{array}$ & 07/15.0 & 22.9 & 17.1 & Grade I-23.1 & 13 \\
\hline $\begin{array}{l}\text { Pilomyxoid } \\
\text { astrocytoma }\end{array}$ & $01 / 2.0$ & - & 1.3 & & \\
\hline SEGA & & & 1.3 & & 2.5 \\
\hline $\begin{array}{l}\text { Pleomorphic } \\
\text { xanthoastrocytoma }\end{array}$ & & & 2.6 & & 1.7 \\
\hline $\begin{array}{l}\text { Diffuse } \\
\text { astrocytoma,NOS }\end{array}$ & $04 / 8.3$ & 11.4 & 10.5 & 5.1 & 9.2 \\
\hline $\begin{array}{l}\text { Anaplastic } \\
\text { astrocytoma, NOS }\end{array}$ & & Grade $3 / 4-14.7 \%$ & 2.6 & Grade 3/4- 6.5 & 2.0 \\
\hline Glioblastoma, NOS & $04 / 8.3$ & & 2.7 & & 2.9 \\
\hline $\begin{array}{l}\text { Oligoastrocytoma,N } \\
\text { OS }\end{array}$ & & & & & 4.1 \\
\hline $\begin{array}{l}\text { Total astrocytic } \\
\text { tumors }\end{array}$ & 33.6 & 49 & 38.1 & 34.7 & 46.8 \\
\hline
\end{tabular}

Table 5 Comparison of non-astrocytic tumours with other studies from India

\begin{tabular}{|c|c|c|c|c|c|}
\hline Study name & $\begin{array}{l}\text { Present study, } \\
\text { No } \%\end{array}$ & $\begin{array}{l}\text { Subhlaxmi et } \\
\text { al, }^{(5)} \%\end{array}$ & $\begin{array}{l}\text { Harshil et al, } \\
\text { (6) } \%\end{array}$ & $\underset{\text { (3) } \%}{\operatorname{Ayu}}$ & $\begin{array}{c}\text { Sangita et al, } \\
\%\end{array}$ \\
\hline Ependymoma & $04 / 8.3$ & $8.1 \%$ & 6.6 & 9.8 & 12.5 \\
\hline Oligodendroglioma, NOS & - & $4.9 \%$ & & 1.1 & 10 \\
\hline Medulloblastoma, NOS & $09 / 19.0$ & $22.9 \%$ & 22.4 & $\begin{array}{l}\text { Medullo +PNET- } \\
22.4\end{array}$ & $\begin{array}{c}\text { Medullo +PNET- } \\
18.4\end{array}$ \\
\hline $\begin{array}{l}\text { CNS Embryonal tumors, NOS/ } \\
\text { PNET }\end{array}$ & $03 / 6.3$ & & 5.3 & & 1.3 \\
\hline Schwannoma & $05 / 10.3$ & & 2.6 & 3.6 & 2.9 \\
\hline Craniopharyngioma & $03 / 6.3$ & $9.8 \%$ & 11.8 & 10.2 & 9.2 \\
\hline SFT/ Hemangiopericytoma & $02 / 4.2$ & & & & \\
\hline
\end{tabular}




\section{JMSCR Vol||07||Issue||02||Page 1121-1126||February}

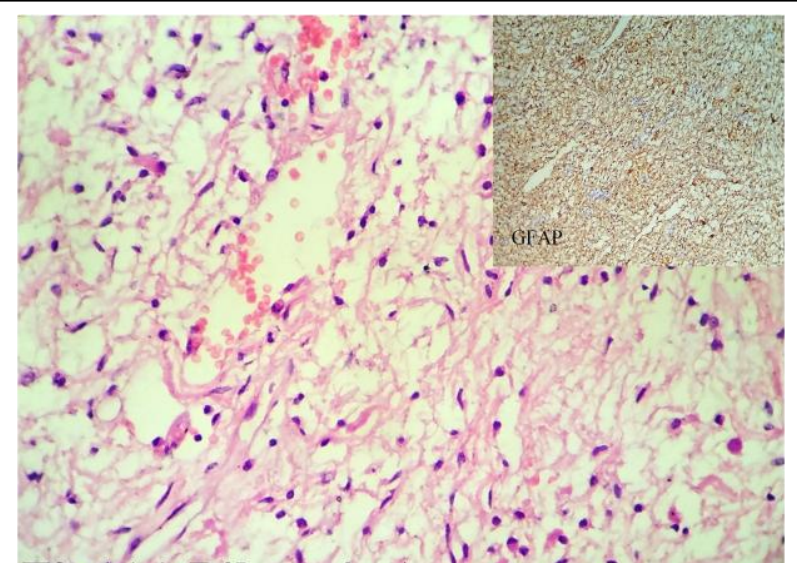

Figr(a) Pilocytic Astrocytoma

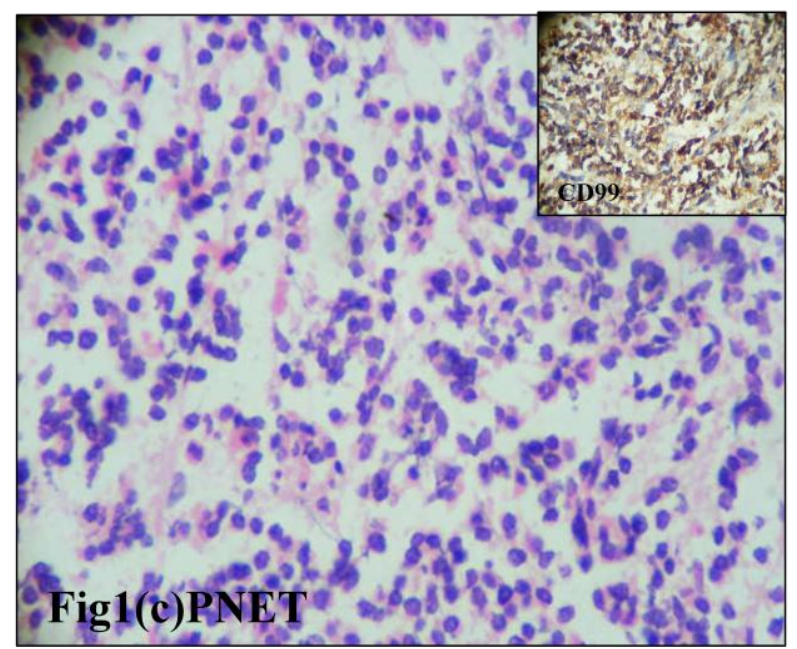

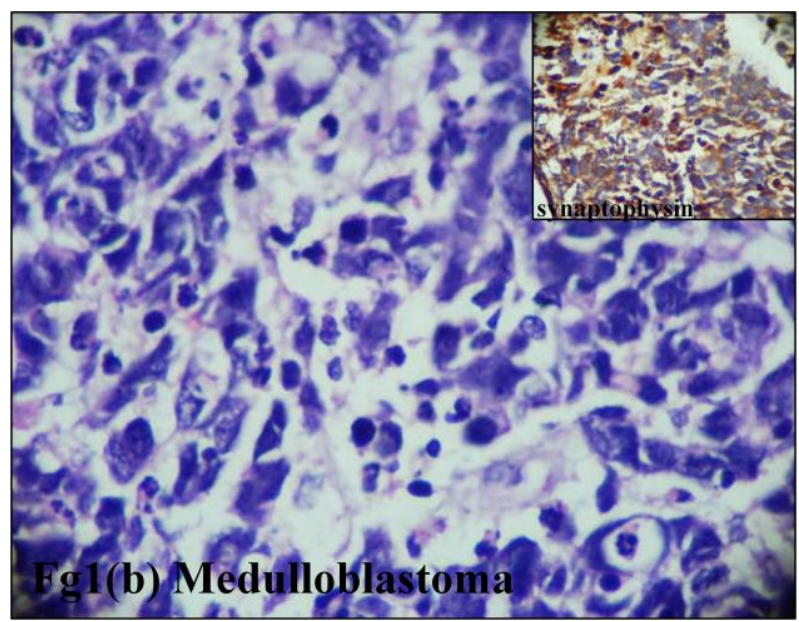

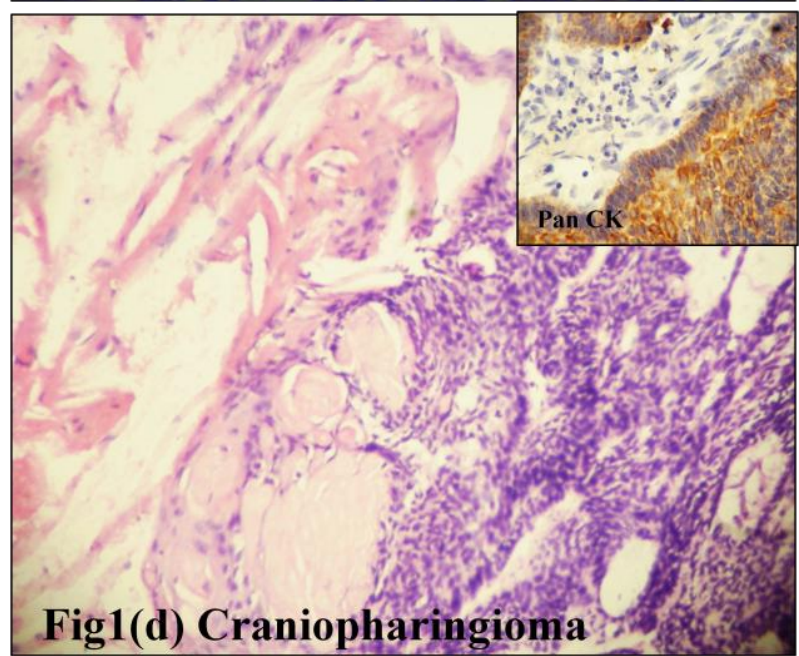

Fig 1. Shows common pediatric tumors with corresponding immunohistochemistry in inset

\section{Conclusion}

The frequencies of various tumors except few at our institute were well within range of national and international data. Astrocytomas and medulloblastomas form major histologic type in pediatric patients followed by embryonal tumors. Infratentorial site is the most common location. This study provides a baseline for understanding the epidemiological aspects of pediatric tumors of the nervous system and opens gate for future studies as per new WHO classification.

\section{References}

1. Rosemberg S, Fujiwara D. Epidemiology of pediatric tumors of the nervous system according to the WHO 2000 classification: a report of 1,195 cases from a single institution. Childs Nerv Syst ChNS Off J Int Soc Pediatr Neurosurg. 2005 Nov;21(11):940-4.
2. Jemal A, Siegel R, Ward E, Murray T, Xu J, Smigal C, et al. Cancer statistics, 2006. CA Cancer J Clin 2006;56:106-30.

3. Jain A, Sharma MC, Suri V, Kale SS, Mahapatra AK, Tatke M, et al. Spectrum of pediatric brain tumors in India: A multiinstitutional study. Neurol India 2011;59:20811.

4. Louis DN, Perry A, Reifenberger G, Deimling A v, Figarella-Branger D, Cavenee WK et al. The 2016 World Health Organization Classification of Tumors of the Central Nervous System: a summary. Acta Neuropathol. 2016;131:803-20.

5. Sengupta S, Chatterjee U, Banerjee U, Ghosh S, Chatterjee S, Ghosh A. A study of histopathological spectrum and expression of $\mathrm{Ki}-67, \mathrm{TP53}$ in primary brain tumors of pediatric age group Indian 
Journal of Medical and Paediatric Oncology2012;33(1);25-31.

6. Shah HC, Ubhale BP, Shah JK. Demographic and histopathologic profile of pediatric brain tumors: A hospital based study. South Asian J Cancer 2015 ;4:146148

7. Margam S R, Gadgil N M, Kshirsagar GR, Gaikwad VP, Kumavat PV, Chaudhari CS. The Histopathological and Epidemiological Study of Pediatric Brain Tumors in A Tertiary Care Hospital, Mumbai. Annals of Pathology and Laboratory Medicine 2016;03(05);375-81.

8. Kaatsch P, Rickert CH, Kühl J, Schüz J, Michaelis J. Population-based epidemiologic data on brain tumors in German children. Cancer 2001;92:3155-64.

9. Ahmed N, Bhurgri Y, Sadiq S, Shakoor KA. Pediatric brain tumours at a tertiary care hospital In Karachi. Asian Pac J Cancer Prev 2007;8:399404.

10. Ogun, G. O., Adeleye, A. O., Babatunde, T. O., Ogun, O. A., Salami, A., Brown, B. J., \& Akang, E. (2016). Central nervous system tumours in children in Ibadan, Nigeria: a histopathologic study. The Pan African Medical Journal, 24, 34. 2016.24.34.9344.

11. Makino K, Nakamura H, Yano S, Kuratsu J, Kumamoto Brain Tumor Group. Population-based epidemiological study of primary intracranial tumors in childhood. Childs Nerv Syst 2010;26:1029-34.

12. Zhou D, Zhang Y, Liu H, Luo S, Luo L, Dai K. Epidemiology of nervous system tumors in children: A survey of 1,485 cases in Beijing Tiantan Hospital from 2001 to 2005. Pediatr Neurosurg 2008;44:97103.

13. Asirvatham JR, Deepti AN, Chyne R, Prasad MSN, Chacko AG, Rajshekhar V et al. Pediatric tumors of the central nervous system: a retrospective study of 1,043 cases from a tertiary care center in South
India. Childs Nerv Syst. 2011 Aug;27(8):1257-63.

14. Pinho RS, Andreoni S, Silva NS, Cappellano AM, Masruha MR, Cavalheiro $\mathrm{S}$ et al. Pediatric central nervous system tumors: a single-center experience from 1989 to 2009. J Pediatr Hematol Oncol. 2011 Dec;33(8):605-9. 